\title{
The effect of different level of feed intake on the urinary excretion of purine derivatives in Chinese Yellow cattle*
}

\author{
F. Mo ${ }^{1,3}$, Y.X. Wang ${ }^{1}$ Zh. Xing ${ }^{1}$ and X.B. Chen ${ }^{2}$ \\ ${ }^{1}$ State Key Laboratory of Animal Nutrition, China Agricultural University \\ No.2 Yuanmingyuan West Road, Haidian \\ Beijing 100094, P.R. China \\ ${ }^{2}$ International Feed Resources Unit, Macaulay Institute \\ Craigiebuckler, Aberdeen ABl5 8QH, United Kingdom
}

\begin{abstract}
Four Chinese Yellow cattle steers were selected to study the effect of the level of feed intake on the urinary excretion of purine derivatives (PD). The rations of the experiment were mixed rations consisting of a roughage and concentrate in the ratio of 60:40. Four steers were fed at four fixed levels, 95, 80, 60 and $40 \%$ of "voluntary intake", using a $4 \times 4$ Latin square design. The apparent digestibility of organic matter was not significant different among intake levels. The daily excretion of PD showed a linear response to the level of intake. PD excretion ( $\mathrm{Y}, \mathrm{mmol} / \mathrm{d})$ was correlated to digestible organic matter intake $(\mathrm{X}, \mathrm{kg} / \mathrm{d}$ ) according to the following equation, $\mathrm{Y}=20.64 \mathrm{X}+12.47$ $\left(\mathrm{R}^{2}=0.94, \mathrm{n}=4 ; \mathrm{P}<0.01\right)$. The results indicated that $\mathrm{PD}$ excretion in the urine can be used as an index for estimating microbial protein supply in Chinese Yellow cattle.
\end{abstract}

KEY WORDS: cattle, feed intake, purine derivatives

\section{INTRODUCTION}

Purine derivatives (PD) of the urinary excretion of ruminant were highly relating to nucleic acid of microorganism in rumen and small intestine (Verbic et al., 1990) and purine derivatives of the blood (McAllan, 1980). With knowledge

\footnotetext{
${ }^{*}$ Supported in part of a FAO/IAEA co-ordinated Research Project. IAEA Research Contract No: 10563/Regular Budget Fund, a Research Project "Purine derivatives technologies for estimating microbial protein supply in ruminant livestock for improving productivity"

${ }^{3}$ Corresponding author: e-mail: mofang@cau.edu.cn
} 
of the amount of purine derivatives excreted in the urine, the efficiency of rumen fermentation and rumen microbial protein output can be easily estimated from the amount of purine derivatives (PD) excreted in the urine (Fujihara et al., 1987; Chen et al., 1990, 1992). The microbial protein supply to the cattle can be estimated (Chen and Gomes, 1992).

The objective of the study was to examine how PD excretion in Chinese Yellow cattle responded quantitatively to levels of feed intake. It was expected that microbial protein synthesis increased with feed intake. The information would be useful for establishing a method to relate PD excretion and microbial protein supply in this type of animals.

\section{MATERIAL AND METHODS}

\section{Animals, housing and feeds}

Four, two-year-old male Chinese Yellow cattle were used in the experiments $\left(180.0 \pm 5.2, \mathrm{~kg} \mathrm{BW} ; \mathrm{W}^{0.75} 49.14\right)$, and were randomly assigned to the dietary treatments. The cattle were fed at different intake level with diets consisting of rice straw and concentrate in a proportion of 60:40. These diets were chosen to create variation in quantity of feed consumed.

Table 1. Composition and daily intake of nutrients on the four intake levels

\begin{tabular}{lcccc}
\hline Intake level, \% & 95 & 80 & 60 & 40 \\
\hline Ingredients, $\mathrm{kg}$ & & & & \\
$\quad$ maize & 1.10 & 0.93 & 0.70 & 0.46 \\
$\quad$ soyabean meal & 0.38 & 0.32 & 0.24 & 0.16 \\
wheat bran & 0.36 & 0.30 & 0.23 & 0.15 \\
bone meal & 0.02 & 0.02 & 0.01 & 0.01 \\
salt & 0.02 & 0.02 & 0.01 & 0.01 \\
Premix ${ }^{1}$ & 0.02 & 0.02 & 0.01 & 0.01 \\
rice straw & 3.01 & 2.53 & 1.90 & 1.27 \\
& & & & \\
Nutrient composition & 4.91 & 4.14 & 3.10 & 2.07 \\
DM, kg & 4.37 & 3.50 & 2.62 & 1.75 \\
OM, kg & 401.8 & 338.4 & 253.8 & 169.2 \\
CP, g & 64.3 & 51.4 & 38.6 & 25.7 \\
N, g & 2714.0 & 2285.5 & 1714.1 & 1142.7 \\
NDF, g & 1781.9 & 1500.6 & 1125.4 & 750.3 \\
$\quad$ ADF, g & & &
\end{tabular}




\section{Experimental procedure and sample collection}

During the preliminary period, all animals were fed at ad libitum level of intake for a week to determine the highest intake. This level of intake was defined as the voluntary intake for the cattle. During the experimental period four steers were fed at four fixed levels, namely $95,80,60$ and $40 \%$ of voluntary intake, using a $4 \times 4$ Latin square design. Each feeding period lasted for 3 weeks. Table 1 lists the actual intake. During each feeding period, total urine and faeces were collected during the last $5 \mathrm{~d}$ of each feeding period. Urine and faeces samples collected were processed and stored for further analysis according to procedure described in the IAEA TECDOC (1997).

\section{Chemical and statistical analyses}

Feed and faeces samples were analysed for dry matter and organic matter $(\mathrm{OM})$ according to standard procedure. Urine samples were analysed for allantoin and uric acid according to procedure described in the IAEA TECDOC (1997). The "PD" here refers to the sum of allantoin and uric acid in molar units.

$\mathrm{PD}=$ allantoin concentration + uric acid concentration.

PD $(\mathrm{mmol} / \mathrm{d})$ or creatinine $(\mathrm{mmol} / \mathrm{d})$ was the result of an average of all urine collected over five days.

Two-factor ANOVA was performed to compare the differences between the measurements. The relationships between PD excretion and digestible organic matter intake (DOMI) were examined by linear regression analysis. The statistical analysis was aided by Excel (Microsoft Office, 1997).

\section{RESULTS}

The intake of DM varied among treatments according to the intake level planned for the experiment. These trends in the intake of DM were reflected on the intake of OM, nitrogen, digestible OM and NDF. The digestibility of OM was not affected by level of feed intake ( $P>0.05)$. The organic matter digestibility (OMD) of diets given to cattle at four levels of feed intake of 95, 80, 60 and 40\% were $61.51,62.27,65.24$ and 70.49 , respectively.

The urinary purine derivatives (PD) excretion in cattle fed at different levels of intake is shown in Table 3. The intake of digestible OM (DOMI; kg/day) ranged from 1.23 to 2.69 (Table 2). While the excretion of allantoin and total PD ranged from 32.27 to 59.63 and from 39.30 to $71.01 \mathrm{mmol} /$ day, respectively, and thus provided satisfactory variation upon which to test the predictability of excretion of PD using intake of DOM. The dietary treatments however, had strong $(\mathrm{P}<0.001)$ influences 
Table 2. Feed intake, digestibility of dry matter and organic matter of Chinese Yellow cattle fed at four intake levels (mean $\pm \mathrm{SD}$ )

\begin{tabular}{lccccc}
\hline Feed intake, \% & \multicolumn{1}{c}{95} & \multicolumn{1}{c}{80} & \multicolumn{1}{c}{60} & 40 & Significant \\
\hline DM intake, $\mathrm{kg}$ & 4.91 & 4.14 & 3.10 & 2.07 & \\
OM intake, kg & 4.37 & 3.50 & 2.62 & 1.75 & \\
DM of faeces, $\mathrm{kg}$ & $2.02 \pm 0.122$ & $1.50 \pm 0.106$ & $1.10 \pm 0.116$ & $0.62 \pm 0.071$ & $*$ \\
OM of faeces, $\mathrm{kg}$ & $1.68 \pm 0.102$ & $1.25 \pm 0.089$ & $0.91 \pm 0.091$ & $0.52 \pm 0.064$ & $*$ \\
DM digestibility, \% & $58.69 \pm 2.49$ & $61.74 \pm 2.71$ & $62.56 \pm 3.94$ & $68.39 \pm 3.60$ & $\mathrm{NS}$ \\
OM digestibility, \% & $61.51 \pm 2.36$ & $62.27 \pm 2.53$ & $65.24 \pm 3.47$ & $70.49 \pm 3.65$ & $\mathrm{NS}$ \\
Digestible OM, kg & $2.69 \pm 0.10$ & $2.18 \pm 0.88$ & $1.71 \pm 0.91$ & $1.23 \pm 0.64$ & $*$ \\
\hline
\end{tabular}

* difference significantly, $\mathrm{P}<0.05$

on the content of PD and creatinine in the urinary samples. The mean contents were highest with $95 \%$ intake diet and lowest with $40 \%$ intake diet.

Table 3. Urinary PD excretion in the cattle fed at different levels of intake (mean $\pm \mathrm{SD}$ )

\begin{tabular}{lrrrrc}
\hline Feed intake, \% & \multicolumn{1}{c}{95} & \multicolumn{1}{c}{80} & \multicolumn{1}{c}{60} & \multicolumn{1}{c}{40} & Significant \\
\hline Allantoin, mmol/d & $59.63 \pm 7.44$ & $43.92 \pm 2.55$ & $39.78 \pm 2.95$ & $32.27 \pm 4.08$ & $* *$ \\
Uric acid, mmol/d & $11.37 \pm 1.43$ & $8.75 \pm 0.95$ & $8.34 \pm 0.57$ & $7.03 \pm 0.90$ & $* *$ \\
PD, mmol/d & $71.01 \pm 8.68$ & $52.67 \pm 2.75$ & $48.13 \pm 3.36$ & $39.30 \pm 4.89$ & $* *$ \\
Creatine, $\mathrm{mmol} / \mathrm{d}$ & $59.42 \pm 5.57$ & $48.63 \pm 3.63$ & $51.72 \pm 2.83$ & $51.90 \pm 4.33$ & $\mathrm{~ns}$ \\
Allantoin, $\mathrm{mmol} / \mathrm{l}$ & $10.65 \pm 1.34$ & $9.98 \pm 0.89$ & $10.45 \pm 0.97$ & $9.78 \pm 1.14$ & $\mathrm{~ns}$ \\
Uric acid, $\mathrm{mmol} / \mathrm{l}$ & $2.03 \pm 0.24$ & $1.99 \pm 0.22$ & $2.19 \pm 0.15$ & $2.13 \pm 0.29$ & $\mathrm{~ns}$ \\
PD, $\mathrm{mmol} / \mathrm{l}$ & $12.68 \pm 1.56$ & $11.97 \pm 1.08$ & $12.67 \pm 1.01$ & $11.91 \pm 1.48$ & $\mathrm{~ns}$ \\
DOM intake, $\mathrm{kg} / \mathrm{d}$ & $2.69 \pm 0.10$ & $2.18 \pm 0.88$ & $1.71 \pm 0.91$ & $1.23 \pm 0.64$ & $* *$ \\
\hline
\end{tabular}

** difference significantly, $\mathrm{P}<0.01$, ns - no difference, $\mathrm{P}>0.05$

The daily excretion of allantoin and uric acid showed a positive response to the level of intake. The PD excretion was increased significantly with increasing level of digestible organic matter intake (DOMI). PD excretions in urine were correlated to DOMI in a consistent manner in the experiments as shown in Figure 1. Using the combined data sets, the correlation between PD excretion (Y, mmol/d) in urine and DOMI (X, kg/d) can be described as follows:

$$
\mathrm{Y}=20.64 \mathrm{X}+12.47\left(\mathrm{R}^{2}=0.94 ; \mathrm{n}=4 ; \mathrm{P}<0.01\right)
$$




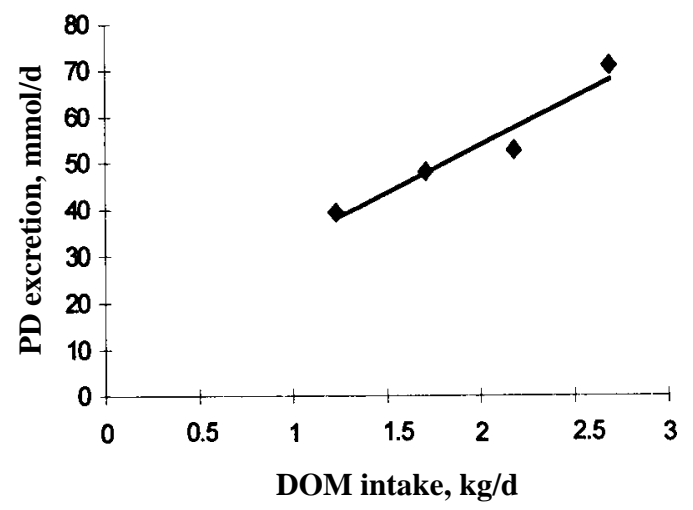

Figure 1. Urinary purine derivatives excretion in Chinese Yellow cattle as a function of digestible organic matter intake

\section{DISCUSSION}

The linear response of the PD excretion to feed intake indicated that PD excretion in the urine can be used as an index for estimating microbial protein supply in Chinese Yellow cattle. When examining the quantitative aspects of this response, it is interesting to note that the slope of the regression $(20.64 \mathrm{mmol} \mathrm{PD} /$ $\mathrm{kg}$ DOMI was rather close to those reported for European B. taurus cattle - 18.5 (Giesecke et al., 1993) and 18.4 (Daniels, 1993) mmol PD/kg DOMI). Creatinine excretion of $1.08 \mathrm{mmo1} / \mathrm{kgW}^{0.75} / \mathrm{d}$ was also close to the values $(0.90 \sim 1.00 \mathrm{mmol} /$ $\mathrm{kgW}^{0.75} \mathrm{~d}$ ) reported in the literature (Chen and Gomes, 1992; Daniels, 1993).

In this work, the correlation equation between the purine absorption and PD excretion was not determined. This equation would enable the calculation of microbial protein supply from PD excretion. However, if we use the data from Friesian steers (Verbic et al., 1990) and the model described (IAEA TECDOC, 1997), the calculated efficiency of microbial protein supply, expressed as $g$ microbial N/kg fermented organic matter intake (FOM), ranged from 20-30, increasing with feed intake (Mo et al., 1994). These values are within the range reported in the literature.

Until the quantitative relationship between PD excretion and purine absorption is determined, measurement of PD excretion in the urine may not provide an exact value of microbial protein supply. However, the measurement is useful as an index to compare microbial protein supply between dietary treatments, thus making it a powerful aid to study how best the local feed resources are being utilized by Chinese Yellow cattle. 


\section{REFERENCES}

Chen X.B., Gomes M.J., 1992. Estimation of microbial protein supply to sheep and cattle based on urinary excretion of purine derivatives. An overview of the technical details. Occasional Publication. International Feed Resources Unit, Rowett Research Institute, Bucksburn, Aberdeen AB2 9SB (UK), pp. 19

Chen X.B., Hovell F.D., Ørskov E.R., Brown D.S., 1990. Excretion of purine derivatives by ruminants: effect of exogenous nucleic acid supply on purine derivative excretion by sheep. Brit. J. Nutr. 63, 131-142

Chen X.B., Ørskov E.R., Osuji P.O., 1992. Effect of feeding frequency on diurnal variation in plasma and urinary purine derivatives in steers. Anim. Prod. 55, 185-191

Daniels Z.M., 1993. Purine derivatives in urine and plasma of lactating cows given different levels of feed intake, MSc. Thesis, University of Aberdeen (UK)

Fujihara T., Ørskov E.R., Reeds P.J., Kyle D.J., 1987. The effect of protein infusion on urinary excretion of purine derivatives in ruminants nourished by intra-gastric nutrition. J. Agr. Sci. $109,7-12$

Giesecke D., Blasliemker J., Südekum K.H., Staingassinger M., 1993. Plasma level, clearance and renal excretion of endogenous and ruminal purines in the bovine, J. Anim. Physiol. Anim. Nutr. 70, 180-189

International Atomic Energy Agency, 1997. Estimation of Rumen Microbial Protein Production from Purine Derivatives in Urine. IAEA-TECDOC-945, IAEA. Vienna, pp. 22-44

McAllan A.B., 1980. The degradation of nucleic acids in, and the removal of breakdown products from the small intestines of steers. Brit. J. Nutr. 44, 99-112

Mo F., Feng Y.L., Zhang X.M., Yang Y.F., 1994. Estimating microbial protein synthesis in the rumen of sheep. Acta Agr. Univ. Pekinensis 20, 445-550

Verbic J., Chen X.B., MacLeod N.A., Ørskov E.R., 1990. Excretion of purine derivatives by ruminants. Effect of microbial nucleic acid infusion on purine derivative excretion by steers. J. Agr. Sci. 114, 243-248 